\title{
LA LÍRICA GALLEGOPORTUGUESA \\ EN LOS PROCESOS DE HEGEMONIZACIÓN Y CANONIZACIÓN DE LA LITERATURA GALLEGA ${ }^{1}$
}

\author{
THE GALICIAN-PORTUGUESE LYRIC \\ AND THE HEGEMONIZATION AND CANONIZATION PROCESSES \\ OF THE GALICIAN LITERATURE
}

SANTIAGO GUTIÉRREZ GARCÍA Universidade de Santiago de Compostela

\begin{abstract}
Resumen: Estudio de la recepción de la lírica gallegoportuguesa y del papel que esta escuela poética desempeña en los respectivos discursos de hegemonización de las literaturas gallega y portuguesa. Las estrategias de apropiación simbólica que utilizan ambas literaturas estarán determinadas por sus diferentes grados de institucionalización, ya que la gallega se encuentra en situación de minorización y la portuguesa actúa desde una posición hegemónica. No obstante, este tipo de enfrentamientos se sitúan en un marco de relaciones más amplio, que contempla una continuidad cultural entre Galicia y Portugal, al menos en los siglos XIII y XIV.
\end{abstract}

Palabras clave: Lírica gallegoportuguesa; Literatura gallega; Literatura portuguesa; Historiografía literaria; Teoría de la Literatura.

\begin{abstract}
Study of the reception of the Galician-Portuguese lyric and its function in the hegemonization strategies of both Galician literature and Portuguese literature. The ways for the symbolic apropriation uttered by these literatures are determined by the different level of institutional development, because of the minorizated condition of the Galician literature and the hegemonic position of the Portuguese one. However, this confrontment belongs to a wide web of relations based on the cultural continuity between Galicia and Portugal, at least to the 13th and 14th centuries.
\end{abstract}

Keywords: Galician-Portuguese lyric; Galician literature; Portuguese literature; Literary history; Literary theory.

El estudio de la literatura suele llevarse a cabo de acuerdo con los principios de origen romántico, que, enmarcados en los procesos de construcción nacional, buscaban su cohesión interna a través de elementos identitarios que permitiesen la diferenciación de unas colectividades respecto a otras. Esto se debe a que la lengua ha sido considerada a menudo expresión

\footnotetext{
${ }^{1}$ El presente artículo forma parte del proyecto de investigación $O$ Cancioneiro de Xograres Galegos. Edición crítica (en formato impreso e electrónico). dirigido por la Prof. M. Brea y asimismo, beneficiado con una ayuda de la Universidad de Santiago de Compostela para una estancia de investigación en la Universidade de Coimbra. Nuestro agradecimiento, en fin, al Prof A. Resende de Ollveira, de esta última Universidad, por la ayuda desinteresada que nos prestó durante la realización de este trabajo.
} 
del espíritu de un pueblo y, con ella, la literatura vista como manifestación artística en la que se reflejaba ese mismo Volkgeist y, al mismo tiempo, como motivo de orgullo que demostraba el alto grado de desarrollo moral de una nación y, por extensión, de sus integrantes ${ }^{2}$. Su importancia en los diversos procesos identitarios que comenzaron en la segunda mitad del siglo XVIII se muestra en la vinculación que desde muy temprano estableció con las instituciones políticas ${ }^{3}$, así como en el surgimiento del concepto de literatura nacional, que consagraba, dentro de una perspectiva histórica, un canon de autores y obras adscribibles a una comunidad ${ }^{4}$.

Tras su consolidación, estos rígidos principios se aplicaron de modo paradigmático en la disciplina que no tardó en conocerse como Historia de la Literatura, en la que se mostraron problemas metodológicos insolubles desde el momento en que se superaban los presupuestos generales que le servían de base y se intentaba trascender el nivel performativo y superficial de una planificación doctrinal asentada sobre el sistema educativo de los diferentes estados nación. Entre estas cuestiones de difícil solución estaría la aplicación de sus esquemas, basados en los presupuestos sociales y culturales de la Edad Contemporánea, a fases históricas lejanas, como la Edad Media, en las que ni existía el concepto de nación ni las lenguas estaban al servicio de un discurso de reafirmación étnica ${ }^{5}$. A pesar de esto, sobre los siglos medievales se proyectaron buena parte de los prejuicios de la mentalidad romántica, acentuados, además, por el prurito de excelencia que ofrecían los tiempos remotos a través del criterio de antigüedad. De este modo, la labor de la crítica se vio condicionada desde que, de la mano de la naciente Filología, aparecieron los primeros estudios con pretensiones científicas sobre la

\footnotetext{
${ }^{2}$ Itamar EVEN-ZOHAR, La función de la literatura en la creación de las naciones de Europa, en D. Villanueva (coord.), "Avances en Teoría de la Literatura", Santiago de Compostela, 1994, p. 370. A este respecto, José LAMBERT, Aproximaciones sistémicas y la literatura en las sociedades multilingües, en M. Iglesias Santos (coord.), "Teoría de los polisistemas", Madrid, 1999 p. 55 , observa que es la institucionalización la que concede a ciertas prácticas lingüísticas
codificadas el estatuto de lengua.

${ }^{3}$ En un sentido amplio, Itamar EVEN-ZOHAR, Factores y dependencias en la cultura. Una revisión de la teoría de los polisistemas, en Iglesias Santos, "Teoría op. cit.", p. 49, define la institución como «el conjunto de factores implicados en el control de la cultura», intermediarios «entre las fuerzas sociales y los repertorios de la cultura». No obstante, este mismo autor precisa a continuación que «los miembros más visibles de la institución tal vez sean los agentes oficiales que forman parte de la administración» (ibid, p. 50).

${ }^{4}$ Vid., por ejemplo, el papel de la literatura en la conformación de un elenco de rasgos identitarios en Anne-Marie THIESSE, La creation des identités nationales, Paris, 1999, p. 14. EVEN-ZOHAR, La función art. cit., pp. 357-377, LAMBERT, Aproximaciones art. cit., pp. $5 \dot{8}-60$. Para la importancia del criterio linguístico en la conformacion de una literatura nacional, vid. Naftali BASSEL, National Literature and Interliterary System, "Poetics Today", XII (1991), pp. 777-778. Segụn declara Xoán GONZÁLEZ-MILLAN, O criterió filolóxico e a confíguración dunha literatura nacional: achegas a un novo marco de reflexión, "Cadernos de Linguaa," XVIII (1998), p. 17, «cando a lingua funciona como o alicerce dunha determinada identidade colectiva, a literatura, sintetizada nos textos canónicos, constitúese igualmente nun instrumento privilexiado de lexitimación e institucionalización da identidade nacional».

${ }^{5}$ Vid. para esta cuestión Alberto VARVARO, Storia delle letterature medievali o della letteratura medievale? Considerazioni su spazi, tempi e ambiti della storiografia letteraria, en A. Asor Rosa (ed.), "La scrittura e la storia. Problemi di storiografia letteraria", Firenze, 1995, pp. 131-142.
} 
literatura medieval ${ }^{6}$, hace casi doscientos años, consiguiendo imponerse estos prejuicios incluso cuando se aplicaba una perspectiva comparatista, como era la propia de la incipiente Romanística.

Una de las consecuencias de este desenfoque epistemológico resultó ser la búsqueda obsesiva de los orígenes de los diversos géneros literarios, como la épica o la lírica románicas ${ }^{7}$. Otra, relacionada, sin embargo, con la anterior, fue la carrera que se estableció entre las lenguas nacionales con el propósito de aducir las más antiguas manifestaciones literarias. Así surgieron, por ejemplo, los largos debates alrededor de qué tradición lírica o épica antecedía a sus equivalentes en otras lenguas, lo que dio lugar a la datación en exceso temprana de ciertas obras. El caso más conocido, por lo que respecta a las literaturas hispánicas, es la fijación de 1142 como año de composición del Cantar de mío Cid por parte de Menéndez Pidal ${ }^{8}$, pero en esta misma línea de actuación podrían incluirse la polémica sobre la supuesta existencia de una primitiva lírica castellana, hoy perdida, o la reivindicación, por parte de la crítica española, de las jarchas mozárabes y su asimilación al canon de la literatura castellana ${ }^{9}$.

No menos importante que las anteriores distorsiones, que los presupuestos nacionalitarios impusieron al estudio de la literatura medieval, fue el análisis de esta última, a partir del sistema de compartimentos estancos, de acuerdo con la segmentación que imponían bien los estados nacionales modernos, bien un simple criterio lingüístico basado en el juego de hegemonización canonizadora, según la perspectiva del siglo XX. De este modo quedó olvidada la producción cultural mediolatina ${ }^{10}$, incompatible con la citada metodología por su condición transnacional - o mejor, anacional ${ }^{11}-$, pero que, precisamente por esta característica, definía la realidad de la Europa de los siglos medios de manera más acertada que las manifestaciones escritas de las lenguas vulgares. No obstante, incluso cuando se obviaba la naturaleza intersistémica de la literatura medieval y se optaba por el enfoque parcial de

${ }^{6}$ El desarrollo de la Filología durante los siglos XVIII y XIX y sus implicaciones políticas e ideológicas ha sido tratado por Edward SAID, Orientalismo, Barcelona, 2003.

${ }^{7}$ Lorenzo RENZI, Introducción a la Filología Románica, Madrid, 1982, p. 103.

${ }^{8}$ Ramón MENÉndez PIDAL, Cantar de Mío Cid. Texto, gramática y vocabulario Madrid, 1964 $\left(1^{\text {a }}\right.$ ed. 1944$)$, I, pp. 19-28. ${ }^{9}$ Un resumen de la cuestión en Pilar VÁZQUEZ CUESTA, Literatura gallega, en J. M. Díez
Borque (coord.), "Historia de las literaturas hispánicas no castellanas", Madrid, 1980, pp. 63560, especialmente pp. 649-60, donde se cuestionan desde el lado gallego las estrategias de asimilación por parte del sistema castellano, en el marco de la polémica por los orígenes de la 2002, pp. 7 y ss., donde se critican las distorsiones que los diversos enfoques nacionales imponen al estudio de la lírica medieval hispana.

${ }^{10} \mathrm{El}$ estudio de la cultura mediolatina, dentro de la reivindicación del espacio cultural europeo, es la base del libro de Ernst ROBERT CURTIUS, Literatura europea y Edad Media latina, Madrid,
1989 (1 ${ }^{\text {a }}$ ed. 1948).

${ }^{11}$ Así, BASSEL, National Literature art. cit., p. 774, señala que el concepto de literatura nacional debe vincularse con la consolidación de los grupos étnicos bajo la idea de nación, que tiene lugar en la sociedad capitalista, de ahí que, recoglendo las ideas de Durisin distinga un período prenacional, al que califica de medieval ethnic titerature. 
los diversos vulgares, no por eso se solventaban los problemas suscitados por las limitaciones de las historias literarias nacionales.

En efecto, la pretensión de trabajar con entidades lingüísticas cohesionadas y de límites precisos ${ }^{12}$ se enfrentaba con las fronteras fluctuantes de la realidad medieval, que disponía las lenguas como códigos poéticos asociados a un registro artístico concreto independientemente de su adscripción a un territorio o a un grupo humano, lo que favorecía el empleo de un idioma con fines estéticos en situaciones de alofonía ${ }^{13}$. Así sucedía con el francés en el norte de Italia, que se utilizaba en la composición de obras narrativas, o con el occitano en la Corona de Aragón y asimismo en el norte de Italia, usado tanto en la lírica como en la narrativa - según demuestra el roman de Jaufre- - Un caso semejante es el que presenta la lírica gallegoportuguesa, que consagró un mismo código idiomático para la poesía lírica en los reinos centrales y occidentales de la península Ibérica.

Ahora bien, frente a los anteriores, en este último ejemplo se suscita un problema añadido. Mientras que en Italia o en Cataluña la lengua literaria actúa en un contexto claramente alófono, que incluso puede favorecer la consideración positiva del código importado, en la lírica gallegoportuguesa tal condición sólo se da en lo que respecta a los reinos de Castilla y León. En cambio, entre Galicia y Portugal se establece una lengua común, identificada como propia ${ }^{14}$, por más que al hablar de la lírica se tenga en cuenta un componente de artificiosidad derivado de su naturaleza poética convencional ${ }^{15}$. Esta circunstancia conllevó la reivindicación del corpus lírico trovadoresco por parte de dos sistemas literarios, el portugués y el gallego, lo que ha tenido consecuencias en un doble sentido, ya que, si bien pudo favorecer el acercamiento entre ambos sistemas, los condicionantes que impone el concepto

\footnotetext{
${ }^{12}$ Mario J. VALDÉS, y Linda HUTCHEON, Rethinking Literary Theory Comparatively, "American Council of Learned Societies" Occasional Paper 27, 1994, en http://www.acls.org/op27.htm [fecha de consulta: 27-8-05], por ejemplo, destacan los riesgos nacionales, que trabajan con entidades monolíticas desde el punto de vista linguístico.

${ }^{13}$ Gérard GONFROY, Les genres lyriques occitans et les traités de poétique: de la classification médiévale à la typologie moderne en D. Kremer (ed.), "Actes du XVIIII ${ }^{\mathrm{e}}$ Congrès International de Linguistique et de Philologie Romanes. Université de Trèves (Trier) 1986",
Tübingen, 1988, VI, p. 125 .

${ }^{14} \mathrm{En}$ este sentido, las gramáticas históricas designan como "etapa gallegoportuguesa" el período que se extiende desde los orígenes hasta mediados del siglo XIV. Incluso cuando se prolonga hasta el siglo XVI, como hace Clarinda DE AZEVEDO MAIA, História do galego-
português. Estado linguistico da Galiza e do Noroeste de Portugal desde o século XIII ao XVI português. Estado linguístico da Galiza e do Noroeste de Portugal desde o século XIII ao XVI (Com referéncia à situação do galego moderno), Lisboa, 1997, p. 1, se establece la mitad del designación remonta a la Grammaire comparée de Raynouard, quien, siguiendo un comentario de B. J. de Figueiredo e Silva, caracteriza la lengua del Cancioneiro, da Ajuda como «portugais de B. J. de Figueiredo e Silva, caracteriza la lengua del Cancioneiro da Ajuda como "portugais
gallicien" (François-Juste-Marie RAYNOUARD, Grammaire comparée des langues de l'Europe
latine dans leurs rapports avec la langue des troubadours, en Grammaire comparée des langues de l'Europe latine. Grammaire romane ou grammaire de la langue des troubadours, Geneve,
1976 (1'a ed. 1816-1821), p. xli, nota 3).

${ }^{15}$ Esta condición de koiné, por lo demás, se da igualmente en la lírica occitana. Para el,caso gallego, vid., entre otros, Manuel RODRIGUES LAPA, Lições de Literatura Portuguesa. Epoca Medieval, Coimbra, 1952 (1 1934$)$, p. 201) y Giuseppe TAVANI, A poesía lírica galegoportuguesa, Vigo, 1986, pp. 33-34.
} 
de literatura nacional han determinado un proceso de apropiación simbólica, a veces vivido en términos de rivalidad más o menos implícita.

De todas formas, la consideración que la lírica medieval recibe por parte de ambas literaturas refleja su dispar grado de jerarquización. Mientras que la portuguesa actúa en el marco de una canonización plena y no discutida, la gallega se caracteriza por su situación de dependencia ${ }^{16}$ en el conjunto del sistema literario ibérico ${ }^{1}$. Esto quiere decir que esta segunda se encuentra en un estado de institucionalización deficiente, que la sitúa en una posición vicaria respecto al centro hegemónico que representa la literatura castellana ${ }^{18}$. Esta condición de minorización determina una serie de características que no se observan en el caso portugués. Así, la situación de deficiencia discursiva en la que se encuentra la literatura gallega acentúa, como sucede en otros sistemas periféricos, la necesidad de reivindicación en la procura de superar las carencias de un repertorio incompleto y las lagunas de un desarrollo histórico discontinuo o de hallar las causas históricas de su minorización ${ }^{19}$. Tales estrategias discursivas, en fin, se ponen al servicio de un proceso de apropiación simbólica que desemboca en la plurifuncionalidad del discurso historiográfico y en la importancia hipertrofiada de los elementos nacionalita$\operatorname{rios}^{20}$. De este modo la literatura se habilita como espacio de resistencia desde la que combatir una situación de subalternidad ${ }^{21}$.

De acuerdo con esta condición problemática de la literatura gallega, las relaciones de fuerza que se establecen identifican un oponente en el sistema castellano, del que busca diferenciarse; de ahí la posibilidad de adoptar la portuguesa como referente de (re)integración ${ }^{22}$. Esto implica la revalorización del corpus poético trovadoresco, ya que actúa como marca de reafirmación del

\footnotetext{
${ }^{16}$ Itamar Even-Zohar, Polisystem Theory, "Poetics Today", XI (1990), p. 7-94.

${ }^{17}$ Arturo CASAS VALES, Problemas de Historia Comparada: la comunidad interliteraria ibérica, "Interlitteraria", 5' (2000), pp. 73-74 califica el espacio geocultural ibérico como (macro)polisistema o incluso polisistema interliterario ibérico, en tanto que agrupa un conjunto de literaturas nacionales entre las que se ha establecido, a lo largo de la Historia, una red de interferencias y relaciones jerárquicas.

${ }^{18}$ Como señala Xoán GonZÁLEZ-MILlán, Do nacionalismo literario a unha literatura nacional. Hipóteses de traballo para un estudio institucional da literatura galega, "Anuario de Estudios Literarios Galegos", 1994, pp. 68, el desarrollo institucional pleno, que se liga a la condición nacional de un sistema literario, implica el establecimiento de esquemas culturales
diferenciados.

${ }^{19} \mathrm{La}$ vinculación entre desarrollo institucional y creación de un repertorio, así como el papel que desempeña en la configuración identitaria de un grupo ha sido puesta de relieve por EVENZOHAR, Factores y dependencias art. cit.", pp. 31-33 y 42-43).

${ }^{20}$ EVEn-ZOHAR, Factores y dependencias art. cit., pp. 67-81; Antón FIGUEROA, Nación, literatura, identidade. Comunicacion literaria e campos sociais en Galicia, Vigo, 2001, p. 60.

${ }^{21}$ Vid. Xoán GoNZÁLEZ-MILlán, Resistencia cultural e diferencia histórica. A experiencia da subalternidade, Santiago de Compostela, 2000, especialmente pp. 73-77.

${ }^{22}$ Pilar VÁZQUEz CUESTA, Portugal e nós, “A Trabe de Ouro”, II / 6 (1991), p. 192. Para este concepto y su complementario, el referente étnico de exclusión, que en el caso gallego representa Castilla, vid. Ramón MÁIZ, A idea de nación, Vigo, 1997, pp. 317-324. Un ejemplo de este mecanismo de reafirmación sería el discurso de Carré Alvarellos con motivo de su ingreso en la Real Academia Galega en el año 1945, donde sostiene que en la «Edad Media el gallego y el portugués son uno mismo" (Leandro CARRÉ ALVARELLOS, El idioma gallego en la Edad
Media. Discurso leido en el acto de su recepción el día 3 de marzo de 1945, por el senor D
Leandro Carré Alvarellos y respuesta del Ilmo. Sr. D. José Filgueira Valverde, Vigo 1973 (1 Leandro Carré Alvarellos y respuesta del Ilmo. Sr. D. José Filgueira Valverde, Vigo, 1973 (1 ${ }^{\text {a }}$
ed. 1945), p. 19), lo que demuestra aduciendo cantigas de Johan Airas de Santiago y Don Dinís.
} 
sistema gallego, en la medida en que muestra la confluencia con otro sistema ajeno al castellano y, por lo tanto, el período de su desarrollo se ofrece como etapa de esplendor ${ }^{23}$. Es decir, que su existencia permite la identificación con la fase inicial de desarrollo truncado que suelen presentar los sistemas periféricos y que acostumbra a situarse en el período medieval; pero además, permite la configuración de un subsistema literario propio, el gallegoportugués, que, nucleado alrededor de la escuela trovadoresca, a veces se prolonga hasta la batalla de Aljubarrota (1385) o incluso hasta mediados del siglo XV, buscando así su coincidencia con la cronología convencional de la Edad Media $^{24}$.

No obstante, y a pesar de la función positiva, desde el punto de vista identitario, que desempeña la literatura portuguesa en lo que respecta al proceso de reivindicación por parte del sistema gallego, entre ambos también se puede establecer una relación de antagonismo a partir, precisamente, de ese espacio común que es la lírica medieval. Aparecen entonces las disintonías características de todo proceso de hegemonización, aunque, claro está, condicionadas por la ya señalada disparidad en el grado de institucionalización de los dos sistemas implicados. En las líneas que siguen repasaremos, sin ánimo de exhaustividad, diversos procedimientos a través de los cuales los sistemas literarios portugués y gallego han procurado legitimarse por medio de la apropiación simbólica de la lírica trovadoresca ${ }^{25}$.

La primera situación de enfrentamiento entre los dos sistemas literarios surge durante el período del redescubrimiento de la lírica medieval a partir de mediados del siglo XIX ${ }^{26}$. Los agentes culturales gallegos contemplaban cómo desde el lado portugués se producía una apropiación de los primeros estudios sobre los cancioneros medievales. El intento de reacción, desde un sistema que, sin embargo, todavía no había consagrado la lengua

\footnotetext{
${ }^{23}$ La consideración positiva de la lírica gallegoportuguesa por parte de la historiografía literaria gallega, así como las consecuencias periodizadoras de esta valorización frente a la prosa medieval o incluso las manifestaciones tardías de la llamada escuela gallegocastellana, la hemos tratado va en Santiago GUTIÉRREZ GARCÍA, Consideracións sobre o periodo medieval na historiografía literaria galega "Boletín Galego de Literatura" XXXI (2004), pp. 29-47. En el caso portugués, la historiografía establece tambón como momento de esplendor p. de la expansión ultramarina, en la medida en que se identifica con el proceso de construcción de la expansión ultramarina, en la medida en que se identifica con el proceso de construcción nacional y se opone a la decadencia de siglos posteriores (Nuno G. MONTEIRO y Antonio COSTA PINTO, Mitos culturales e identidad nacional, en A. Costa Pinto (coord.), "Portugal contemporá-

${ }^{24}$ José Luís RoDRÍGUEZ, O problema dos límites entre as literaturas galega e portuguesa na época medieval, "Nova Renacença", LXXII-LXXIII (1999), pp. 193-204.

${ }^{25}$ Las observaciones que siguen podrían ampliarse con el análisis de otras estrategias que no tratamos por cuestión de espacio, tales como la recreación medievalizante que lleva a cabo la lírica neotrovadoresca, estudiada por Teresa LóPEZ, O neotrobadorismo, Vigo, 1997, y que debe ponerse en relación con la recuperación idealizada del pasado histórico que se produce en los sistemas minorizados. Bajo esta perspectiva se emparenta, por ejemplo, con la readaptación de la materia de Bretaña o con el cultivo de la narrativa alegóricá. Vid. al respecto Xoán GONZÁLEZMILLÁN, Silencio, parodia e subversión. Cinco ensaios sobre narrativa galega contemporánea Vigo, 1991 .

${ }^{26}$ Sobre la recepción de la lírica medieval en la Galicia del siglo XIX, vid. Teresa LóPEZ, Névoas de antano. Ecos dos cancioneiros galego-portuguesas no século XIX, Santiago de Compostela, 1991.
} 
como criterio canonizador ${ }^{27}$, partió de su situación de postración y constituyó un llamamiento a iniciar un proceso paralelo de reivindicación. Así, uno de los condicionantes que estuvo presente en todo momento fue el del retraso de la literatura gallega respecto a otras europeas, entre ellas, claro está, la portuguesa, lo que finalmente dificultaba las estrategias de legitimación. La conciencia de ir por detrás de los eruditos portugueses a la hora de estudiar la lírica medieval desvela, pues, diversas claves a tener en cuenta.

Por una parte, y de modo general, destaca el papel de la Filología en el proceso de canonización literaria, en especial en esos años de consolidación de los estados nación, ya que la citada capacidad de reivindicación dependía del grado de desarrollo alcanzado por esta disciplina. Por otra, se descubre como el desfase entre el sistema hegemónico y el minorizado no era tanto cronológico, sino simbólico, en la medida en que los primeros trabajos se referían a la lírica y a los trovadores como portugueses. Nótese, a este respecto, el comentario de Murguía sobre la edición de Monaci, que en su título calificaba el cancionero $V$ como portugués:

Después del Cancionero del Vaticano, que el editor llamó portugués, y con la misma razón pudiéramos nosotros llamar gallego, nada que mejor y más convenientemente pueda ilustrar nuestro pasado que las Cantigas del Rey Sabio, hasta hoy casi desconocidas ${ }^{28}$.

Junto a esta reivindicación de la lírica a través de las Cantigas de Santa María, el erudito de Arteixo mencionaba la obra de Johan Airas, como ejemplo de trovador gallego ${ }^{29}$.

Ahora bien, hay que tener en cuenta que también los estudios portugueses se encontraban en esta época a remolque de los que se estaban llevando a cabo en otros países de Europa, especialmente en los centroeuropeos, donde la Filología había conseguido un alto grado de desarrollo ${ }^{30}$, de ahí que incluso Braga ${ }^{31}$ actuase desde el convencimiento de que la portuguesa formaba parte de la periferia de las literaturas europeas y que, por lo mismo,

\footnotetext{
${ }^{27} \mathrm{La}$ importancia de la lengua en la articulación de los discursos nacionalitarios ha sido tratada por GONZÁLEZ-MILLÁN, $O$ criterio art. cit., pp. 5-24, especialmente p. 21 , donde establecee el paralelo entre el proceso de canonización lingǘstico y literario y otros procesos de institucionalización nacional.

${ }^{28} \mathrm{El}$ citado pasaje se inserta en un comentario aparecido en La Ilustración Gallega y Asturiana, I (1879), p. 322.

${ }^{29} \mathrm{Ibid}$.

${ }^{30}$ Fidelino DE FigueIREDO, História Literária de Portugal (séculos XII-XX) Coimbra, 1944 p. 77, por ejemplo, observa que hasta el último cuarto del siglo XIX los estudiosos de la lírica gallegoportuguesa fueron sobre todo extranjeros. Vid. una opinión semejante en Henrique MONTEAGUDO, Prólogo, en Armando COTARELO VALledor, Cancioneiro de Paio Gómez Chariño, almirante y poeta (siglo XIII), Santiago de Compostela, 1998 (1 $\left.1^{\text {a }} 1934\right)$, pp. ix-X, que insiste en esta idea y añade la falta de interés de los estudiosos gallegos, centrados en un primer momento en la prosa.

${ }^{31}$ MONTEIRO y PINTO, Mitos culturales art. cit., p. 210, califican a Braga como el gran teórico del nacionalismo republicano portugués, cuya obra estuvo consagrada a una construcción cultural de la nación.
} 
era ignorada en el conjunto de los estudios románicos ${ }^{32}$. Lo que sucedía entonces era que la perspectiva foránea de los primeros filólogos que se acercaban a la lírica peninsular obviaba el sistema minorizado -en el caso que nos ocupa, el gallego- y centraba su atención en el institucionalizado, de tal manera que facilitaba la apropiación por parte portuguesa ${ }^{33}$. Así sucede, por ejemplo, con las ediciones de Monaci, publicadas a partir de $1873^{34}$ o la de Molteni, que salió al público en $1880^{35}$, que se refieren en sus títulos a los cancioneros como portugueses ${ }^{36}$.

Tal situación de desequilibrio no ha impedido que el adjetivo gallegoportugués se consolidase a la hora de designar la escuela lírica medieval, aunque la tensión entre los dos discursos de hegemonización enfrentados ha facilitado la utilización por separado de los términos gallego y portugués, en un intento de tomar la parte por el todo. Obviamente, el uso de uno de estos dos vocablos refleja la intención asimiladora de ambas literaturas, de ahí que se observe una tendencia a ser usado por los autores de los respectivos sistemas, bien de modo exclusivo, bien de manera alterna. Al respecto, basta con leer, desde el punto de vista gallego, los discursos de Murguía y Carré Alvarellos que mencionamos en este mismo trabajo o, desde el portugués, las obras de Braga, por citar sólo tres autores que representan un hábito generalizado en ambas tradiciones críticas. Tal costumbre, en fin, se mantiene bien avanzado el siglo XX, incluso después de que se consolidase el término gallegoportugués y de las observaciones de Rodrigues Lapa ${ }^{37}$ sobre la inadecuación de este tipo de atribuciones nacionalistas en lo que respecta a la poesía trovadoresca. La vigencia de este uso entre los agentes culturales de Galicia se comprueba, sin ir más lejos, en el discurso que pronunció X.L. Méndez Ferrín en 2000, con ocasión de su ingreso en la Real Academia Galega, en el que reclamaba la galleguidad de la lírica medieval y proponía que se abandonase la etiqueta gallegoportuguesa ${ }^{38}$. Por el lado gallego, sin

\footnotetext{
${ }^{32}$ Teóphilo Braga, Historia da Literatura Portugueza, t. I, Idade Media, Porto, 1909, p. III.

${ }^{33}$ En este sentido, la figura de Carolina Michäelis de Vasconcelos, estudiosa alemana que acabó asimilada por el sistema portugués, podría resultar paradigmática. Àsí , por ejemplo, Ramón LORENZO, Vasconcelos, Carolina Michaélis de en G. Lanciani y G. Tavani (ed.), Dicionário da Literatura Medieval Galega e Portuguesa, 1993, Lisboa, p. 654) se refiere a ella como «filóloga portuguesa, de origem alemã».

${ }^{34}$ Ernesto MONACI, Canti antichi portoghesi tratti del codice vaticano 4803, Imola, 1873; Idem, Cantos de ledino tratti del grande canzoniere portoghese della Biblioteca Vaticana, Halle, 1875; Idem, Il canzoniere portoghese della Biblioteca Vaticana, Halle, 1875.

${ }^{35}$ Enrico MOLTENI, Il Canzoniere Portoghese Colocci-Brancuti, publicato nella parti che completano il Codice Vaticano 4803, Halle, 1880.

${ }^{36} \mathrm{Vid}$. la importancia de la contribución alemana e italiana en los primeros estudios sobre lírica gallegoportuguesa en Giuseppe Carlo ROSSI, La filologia italiana e tedesca del Novecento quadro dell'unità culturale europea. Atti del II conveono internazionale di studi italo-tedeschi. Merano, Aprile 5-11 1961", Merano, 1962, pp. 355-61.

${ }^{37}$ LAPA L Licóes op. cit., pp. 96-97.
${ }^{38}$ Xosé Luis MÉNDEZ FERRÍn, A poesía medieval galega vista desde os relanzos derradeiros do seculo $X X$. Discurso lido na recepción pública o día 30 de septembro de 2000 , no acto da sua recepción, A Coruña, 2000.
} 
embargo, la reivindicación se produce, además, desde la literatura castellana, que intenta la construcción de un canon español a partir de su posición de centralidad. Véase, por ejemplo, la insistencia con que R. Menéndez Pidal utiliza el adjetivo gallego/a en su estudio Poesía juglaresca y juglares ${ }^{39}$, que hay que situar entre otros mecanismos de integración de la lírica gallegoportuguesa en el sistema español, como la inclusión de cantigas trovadorescas en antologías de textos ${ }^{40} \mathrm{o}$ incluso en historias de la literatura castellana.

Los elementos que permiten la apropiación simbólica por parte de los sistemas gallego y portugués descubren asimismo otras estrategias de legitimación. Una de ellas parte de las vacilaciones de la literatura gallega para consolidar la lengua como criterio canonizador, fruto de su debilidad institucional ya mencionada. Así, hasta bien avanzado el siglo XX los agentes culturales gallegos optaron por articular su discurso apoyándose, ya que no en la Filología, en las investigaciones históricas de tipo positivista. A este respecto, señala T. López ${ }^{41}$ cómo la producción crítica gallega ha optado por la exhumación de documentos notariales que contuviesen datos históricos sobre trovadores y juglares con los que sustentar la galleguidad de la escuela poética. Quedaba claro, así, que el interés que despertaba la lírica medieval no residía sólo en la apreciación de valores estéticos, sino en su fecha temprana de composición, que le daba la primacía cronológica a la lengua de Galicia sobre los otros idiomas peninsulares, así como el carácter áulico de esta, cuya postración en los días del Rexurdimento contrastaba con su empleo por parte de monarcas y aristócratas medievales ${ }^{42}$. Paradigmáticos de esta estrategia reivindicativa resultan los opúsculos de A. Martínez Salazar, Jograes galegos. Documentos inéditos, y J. Villa-Amil Castro, Outros jograes galegos, que aparecieron en 1896, así como Los trovadores gallegos de M. Murguía, publicado en 1905, ya que todos ellos, desde presupuestos metodológicos diversos, pretendían colaborar al establecimiento de un canon de autores gallegos medievales. La tercera de estas obras incluía, no sólo matizaciones al carácter exclusivista de los trabajos realizados en Portugal, sino incluso un elenco de trovadores de origen galaico. Para su elaboración, Murguía seguía las huellas de A. Neira de Mosquera, quien ya en 1841 había enumerado en un artículo aparecido en El Idólatra de Galicia un breve corpus de poetas

\footnotetext{
${ }^{39}$ Ramón MENÉndez PIDAL, Poesía juglaresca y juglares. Orígenes de las literaturas románicas, Madrid, 1991 (1 $\left.{ }^{\mathrm{a}} 1924\right)$.

${ }^{40}$ Dámaso Alonso y José Manuel Blecua, Antología de la poesía española. Poesía de tipo tradicional, Madrid, 1969 (1 1956$)$.

${ }^{41}$ Teresa LóPEZ, Andrés Martínez Salazar, os xograis galegos e as fanadas edicións galegas dos cancioneiros medievais, en X. A. Fernandez, Roca y M. J. Martínez López (ed.), "Vir bonus dicendi peritus. Homenaxe a José Pérez Riesco", A Coruña, 2002, p. 227.

${ }^{42}$ Teresa LóPEZ, De lírica trovadoresca na Galiza decimonónica: Teófilo Braga e Antonio de la Iglesia, "Nova Renacença", LXXII-LXXIII (1999), pp. 282; FIGUEROA, Nacion, literatura op. cit, p. 87 . Según la opinión de MONTEAGUDO, Prólogo art. cit.", p. xi, «o descubrimento do $o p$. cit, p. 87. Según la opinion de MONTEAGUDO, Prologo art. cit.", p. xi, «o descubrimento do
galego medieval proporcionou ós defensores do galego un poderoso argumento e un sólido apoio
para a súa dignificación», de ahí el impulso que tuvieron los trabajos de corte historicista y para a súa dignificación», de ahí el impulso que tuvieron los trabajos de corte historicista y
biográfico por parte de los estudiosos gallegos. Así, por ejemplo, viḍ. CARRE ALVARELLOS, $E l$ idioma gallego op. cit., p. 14, donde se destacan los cancioneros medievales, a los que se califica de «valiosísimos», por ser «prueba irrefutable de la grandeza espiritual, de la importancia cultura y artística de Galicia... fuente inagotable para el estudio de nuestro idioma vernáculo».
} 
elaborado a partir del Nobiliário del conde D. Pedro de Barcelos, del Cancionero de Baena y del Prohemio e carta del Marqués de Santillana ${ }^{43}$. Por lo demás, Murguía concedía que algunos de los poetas de su corpus podrían no ser gallegos, de ahí que admitiese una hipotética reapropiación de algunos de ellos por parte portuguesa:

\begin{abstract}
Y así añadiré que no aseguro que indudablemente son gallegos, todos los que señalo como tales, no menos que entre los que aparto como lusitanos, no haya alguno que pertenezca á la Galicia actual. Por esto mismo, y á la manera que en los libros de teología, solían terminar sus autores diciendo, que iba su obra y sugetaban á la corrección de la Santa Sede, así va la presente lista á la depuración y sanción de los autores portugueses que de estas materias se ocupan ${ }^{44}$.
\end{abstract}

Tal reivindicación de autores, además de partir del reconocimiento de la inferioridad de los estudiosos gallegos frente a los portugueses, según manifiesta su última afirmación, recoge las dificultades para establecer un canon propio, desde posiciones cercanas a la concepción biografista de la literatura. Esto da lugar, en ocasiones, a disputas entre eruditos de ambos sistemas alrededor de la naturalidad de autores de la escuela trovadoresca, como la que protagonizan J.J. Nunes y M. Amor Meilán sobre Pero de Veer ${ }^{45}$ o la del propio Nunes y A. López Ferreiro sobre el lugar de nacimiento de Johan Garcia de Guilhade ${ }^{46}$. La proliferación de este tipo de pesquisas choca con la concepción de un área cultural común gallegoportuguesa, según se desprende de la observación del mismo Nunes, quien al tiempo que discrimina autores nacidos al norte o al sur del Miño, destaca que por aquel entonces empleaban una misma lengua y que en aquella época «também quási que não havia fronteiras entre eles» ${ }^{47}$.

La postura de enfrentamiento simbólico en la que se sitúan los estudiosos dedicados a este género de trabajos se resume en la propuesta de $\mathrm{V}$. M. de Aguiar e Silva, que, junto con A. da Costa Lopes, sostenía la procedencia portuguesa de Martin de Ginzo ${ }^{48}$. Según el primero de estos estudiosos

não é admissível continuar a inserir calmamente o nome de Martim de Ginzo na teoria dos trovadores e jograis galegos, embora faltem os

\footnotetext{
${ }^{43}$ LÓPEZ, De lírica art. cit., p. 284. 45-46.

${ }_{46}^{44}$ Manuel Murguía, Los trovadores gallegos, Santiago de Compostela, 1998 (1 $\left.{ }^{\text {a }} 1905\right)$, pp.

${ }^{45}$ Manuel AMOR, MEILÁN, El trovador Pedro de Veer no fue bearnés sino lucense, "Boletín

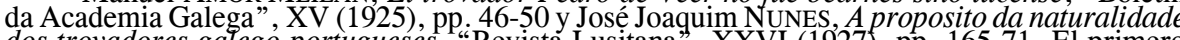
dos trovadores galego-portugueses, "Revista Lusitana", XXVI (1927), pp. 165-71. El primero había situado el lugar de nacimiento del trovador en S. Vicente de Veer, en la provincia de Lugo, mientras que el segundo proponía su naturalidad portuguesa.

${ }^{46} \mathrm{Vid}$. un resumen de la polémica en NUNES, A propósito art. cit., pp. 166 y ss.

${ }^{47}$ Ibid., p. 165.

${ }^{48}$ António DA COSTA LOPES, Martim de Ginzo, jogral português, “4 Ventos”, I (1959), pp. 192-209; Idem, A naturalidade portuguesa do jogral Martim de Ginzo. Anotaçôes críticas, "O Distrito de Braga", II (1964), pp. 177-188.
} 
elementos que permitam incluí-los legìtimamente no grupo dos poetas trovadorescos portugueses ${ }^{49}$,

lo que no deja de ser equivalente a la situación, ya indicada, que suscitaba el canon propuesto por Murguía en Los trovadores gallegos.

Este procedimiento de apropiación, en fin, encuentra un refrendo institucional en fechas más próximas, pues tal es el que adopta la celebración del Día das Letras Galegas (17 de mayo), que, auspiciado por la Real Academia Galega, destaca cada año una figura del canon literario galaico -a veces hasta es este apoyo institucional el que canoniza un autor poco conocido-. Entre los escritores escogidos se cuentan Alfonso X en el año 1980 y tres juglares vinculados, a través de sus cantigas, con la ría de Vigo -más arduo es demostrar su nacimiento en esa comarca-, Martin Codax, Meendinho y Johan de Cangas, que fueron celebrados en 1998. En ambos casos, según las declaraciones de la Real Academia Galega, lo que se pretendía no era exaltar un autor concreto, sino «a nosa poesía medieval ${ }^{50}$.

La inclusión de los trovadores medievales en el discurso historiográfico gallego constituye, asimismo, una respuesta a actuaciones similares por parte del sistema rival. El más preclaro representante del lado portugués es, en este aspecto, T. Braga, que en su Historia da literatura portugueza consideraba la lírica manifestación de la raza lusitana, que se extendería por Galicia y Portugal. No obstante, a pesar de este substrato étnico común, afirmaba que la poesía trovadoresca es «efflorecencia inteiramente portugueza», ligada al surgimiento de la nacionalidad. Por tal razón, establecía un primer foco cultural en la corte de Afonso Henriques en Guimarães ${ }^{51}$, lo que le permitía retrotraer su aparición, en procura de la excelencia de antigüedad, por encima de las otras literaturas ibéricas. La asociación con la consolidación de Portugal como reino tenía consecuencias en un doble nivel. En primer lugar, reforzaba la importancia concedida a la labor institucionalizadora sobre la lengua y la literatura, cuya suerte se unía a la capacidad de intervención desde las instancias políticas. Esto supone, según el punto de vista contrario, que las deficiencias en la consolidación de este tipo de instancias conllevaban la incapacidad tanto de la lengua como de la literatura para desarrollarse. Bajo tal presupuesto, Braga sostenía que Galicia no había participado en este primer impulso, ya que en ese tiempo estaba sometida a León y su lengua quedaba reducida al uso popular ${ }^{52}$.

\footnotetext{
${ }^{49}$ Vítor Manuel DE Aguiar E Silva, Costa Lopes, António - Martim de Ginzo, jogral português. Separata de 4 Ventos, $2^{a}$ série, tomo I (1959), $n^{\text {os }}$ 3-4, Braga, 1960, 23 pp., "Revista de História Literária de Portugal”, I (1962), p. 309.

${ }^{50}$ Xesús Alonso MonTero, Presentación da Academia, do 17 de Maio e da Poesía Medieval, en L. Fontoira e X. L. Couceiro Pérez (eds.), "Martín Codax, Mendiño, Johán de Cangas", Santiago de Compostela, 1998, p. 13.

${ }^{51}$ Braga, Historia op. cit., t. I pp. 135 y 172-76.

${ }^{52} \mathrm{La}$ correlación que el erudito portugués establece entre lengua, literatura, pueblo y estado aparece explicitada en BRAGA, Historia op. cit., I, pp. iii-iv y, sobre todo, en la siguiente declaración, en la que explica la situación de postración del gallego: «Em quanto as Litteraturas castelhana e portugueza avançam para a perfeição esthetica, outras, como a aragoneza valenciana e catalã , que floreceram, extinguiram-se, porque o apoio da nacionalidade reduziu-se
} 
Por lo demás, la interpretación del desarrollo artístico bajo una perspectiva nacionalitaria es asumida asimismo por los agentes culturales gallegos, que, si bien unen la suerte de la literatura a la de la afirmación nacional gallega, no pueden por menos que intentar su legitimación a partir precisamente de lo que les negaba Braga. No por casualidad, desde el punto de vista gallego, los siglos XII y XIII se contemplan como un período de esplendor, en buena medida debido al auge de las peregrinaciones a Compostela y a la eclosión de la poesía trovadoresca, pero también, desde una perspectiva puramente política, a la capacidad de intervención / diferenciación con respecto a la corte castellanoleonesa ${ }^{53}$. Así, los argumentos que aduce Murguía para explicar el surgimiento de la lírica son paralelos -etnia y afirmación nacional- a los que se manejaban desde el lado portugués:

Dos elementos, pues, uno orgánico, la raza, otro de ocasión, la constitución del Estado gallego, prepararon, informaron é hicieron posibles, el grande, el intenso desenvolvimiento intelectual y de grandeza que gozó nuestro país durante el siglo XII, que fué nuestro gran siglo ${ }^{54}$.

En la asimilación por parte gallega del trovadorismo, la reivindicación de una dinastía vernácula permitía argumentos como los de Braga, al tiempo que se reforzaba la autoafirmación respecto al referente de exclusión castellano. Así, recogiendo la idea de Murguía de que la autonomía política le proporcionaba a Galicia un «punto de superioridad intelectual», la historiografía gallega exaltó las figuras destacadas de este período de esplendor, como el rey Don García, el arzobispo de Santiago Diego Gelmírez o Alfonso Raimúndez, hijo de la reina castellana Urraca y él mismo monarca de Castilla ${ }^{55}$. De manera inversa, y partiendo de la situación de minorización gallega, Murguía une también las decadencias lírica y política a través de menciones a los avatares negativos de los últimos siglos de la Edad Media — «tinieblas más grandes y profundas que las que cayeron sobre los tristes días que corren de la segunda mitad del siglo XIV á la segunda mitad también del $\mathrm{XV} »{ }^{56}$ - donde es fácil adivinar alusiones a la entronización de la dinastía Trastámara y de los Reyes Católicos.

Estas alusiones implícitas de Murguía se explicitan, por ejemplo, en Carré Alvarellos ${ }^{57}$, quien, además de calificar el período medieval como el del

a um regionalismo em revolta contra uma incorporação politica e administrativa, como se confirma pela galliziana» (ibid., pp. 137-138)

${ }^{53} \mathrm{La}$ identificación de Galicia con el momento de esplendor de Santiago de Compostela, sobre el que luego volveremos, responde a la necesidad nacionalitaria de reforzar el papel aglutinador de un centro que actúe como capital. Por tal motivo, este período suele denominarse Era Compostelana (Ramón VILlaRES, Breve historia de Galicia, Madrid, 2004, p. 98).

${ }^{54}$ Murguía, Los trovadores op. cit., p. 9.

${ }^{55}$ Vid., por ejemplo, la descripción que reproduce VILLARES, Breve historia op cit. pp 9596) tomada de la Historia Compostellana, de su coronación como rey de Galicia, celebrada en la Catedral de Santiago de Compostela.

${ }^{56}$ Murguía, Los trovadores op. cit., p. 8.

${ }^{57}$ CARré Alvarellos, El idioma gallego op. cit., p. 25. 
«apogeo del gallego», insiste en su unidad con el portugués hasta finales del siglo XI y su decadencia a causa del sometimiento castellano ${ }^{58}$. Es precisamente la proyección de este género de esquemas teleológicos la que determina la disparidad de tono de la crítica gallega respecto de la portuguesa, puesto que sólo esta última puede enlazar con etapas posteriores de la historia literaria, como la del final de la Edad Media y el Renacimiento, que aseguren la continuidad discursiva propia de todo sistema hegemónico ${ }^{59}$.

La otra consecuencia que se deriva de adherir la lírica gallegoportuguesa a los respectivos procesos nacionalitarios consiste en la apropiación por parte portuguesa de los elementos organizativos de la escuela poética; resultado esperable, puesto que, una vez llegados a este punto, Portugal dispone de los tantas veces mencionados mecanismos de institucionalización de los que carece Galicia. Por ejemplo, basta con repasar las diversas propuestas de periodización, entre ellas la de $\mathrm{Braga}^{60}$, que adoptan como hitos temporales los reinados de los sucesivos monarcas lusitanos: ciclo prealfonsino (1185-1248), que abarca los reinados de Sancho I, Afonso II y Sancho II; ciclo alfonsino (1248-1279), alrededor de la figura de Afonso III; ciclo dionisino (1279-1325), que coincide con el reinado de D. Dinis; y ciclo post-dionisino (1325-1354), a partir de la muerte de este monarca hasta la extinción de la escuela. Incluso en otra periodización del mismo crítico, elaborada de acuerdo con la evolución estética de la escuela poética, se establecen las divisiones cronológicas nuevamente según los reinados de la monarquía lusitana: período italo-provenzal (1114-1245), primer período lemosín (1246-1279) y segundo período lemosín (1279-1325), que aunque también recibe el nombre de escuela gallega o estylo galliziano, coincide con el reinado de D. Dinis ${ }^{61}$. La imposible respuesta desde el lado gallego se ve obligada a adoptar la secuencia de reyes castellanos y leoneses, facilitando de este modo la intervención / asimilación del sistema castellano, en especial para

\footnotetext{
${ }^{58}$ Ibid., pp. 19-20.

${ }^{59}$ Vid., por ejemplo, J. DA CUNHA NeVES CARVAlHo, Noticia d'alguns trovadores portuguezes e gallegos nos primeiros seculos da monarchia, e de suas poesias consideradas como elemento de progresso e aperfeiçoamento na lingua nacional, "O Panorama", III (1844), p. 341 que establece una continuidad narrativa entre la tradición trovadoresca y Fernão Lopes, Vasco

${ }^{60}$ BRAGA, Historia op. cit., I, p. 182.

${ }^{61}$ Teóphilo BRAGA, Cancioneiro portuguez da Vaticana. Edição crítica restituida sobre o textos diplomatico de Halle, acompanhada de um glossario e de uma introducção sobre os trovadores e cancioneiros portuguezes, Lisboa, 1878 , pp. lxiii-lxiv. Vid. por su parte, JeanMarie D'HEUR, Troubadours d'oc, et troubadours galichens-portugais. Recherches sur quelques échanges dans la littérature de l'Europe au Moyen Age, Paris, 1873, p. 36, donde se critica justifican y porque omite las características que explicarian unay fechas, como 114 , que no se provenzal. La decuación a la cronología de los sucesivos reyes portugueses se repite en la periodización de Carolina MICHÄELIS DE VASCONCELOS, Cancioneiro da Ajuda, Halle, 1904, II, p. 603, que, aunque parte de la evolución interna de la escuela, organiza las diversas etapas a partir de los hitos cronológicos de la Historia portuguesa: alvorejar: hasta 1185, cuando se inicia el período histórico; madrugada: hasta 1245, período protohistórico; medio-dia: hasta 1280, edad áurea o alfonsina; tarde: hasta 1300 , período dionisíaco; crepúsculo: hasta 1350 , tiempo de los epígonos; noche: de 1350 en adelante, que sirve de transición poética para la segunda época o poesía cancioneril, que obviamente sólo puede ser portuguesa o castellana.
} 
lo que se refiere al período de esplendor de los años centrales del siglo XIII, vinculados a las figuras de Fernando III y Alfonso X.

Una de las consecuencias de esta reapropiación castellana sería el incierto estatuto de las Cantigas de Santa María, concebidas en el ambiente cultural de la corte toledana del rey Sabio. A pesar de las reivindicaciones de los hombres del Rexurdimento, y acabamos de ver un ejemplo extraído de Murguía, el cancionero mariano acabó por ser desplazado del canon gallego ante su cercanía al sistema hegemónico castellano ${ }^{62}$. Otra sería la necesidad de construir una cronología dinástica propia, tal y como intenta algún manual de historia literaria ${ }^{63}$, que aplica una lógica estrictamente gallega a la hora de numerar el orden sucesorio de los monarcas. Bajo esta perspectiva cobran sentido los comentarios de Villares ${ }^{64}$, en los que se observa una decepción implícita por la marcha de Galicia de Alfonso Raimúndez para tomar posesión del trono de Castilla como Alfonso VII.

Sin embargo, la importancia de Alfonso X no se limita a darle nombre a la etapa más importante de la escuela trovadoresca, sino que es precisamente la presencia de los reyes trovadores, como el propio Alfonso o D. Dinis, para lo que afecta a Portugal, la que ha legitimado desde los primeros estudios sobre lírica unos sistemas literarios sobre otros. Así, D. Dinis, que posee el cancionero individual más amplio del corpus trovadoresco ${ }^{65}$, ha sido objeto de edición desde que a mediados del siglo XIX publicase sus poesías C. Lopes de Moura $^{66}$. Mas, gracias a sus cincuenta y una cantigas de amigo, su función, además, ha consistido en asimilar del lado portugués el substrato popular de la lírica, que se considera parte de un acervo común gallegoportugués y que, a la vista del estado de institucionalización deficitaria de la literatura gallega, le concedía a esta una mayor pervivencia de tal tipo de elementos. La estrategia discursiva que hace de D. Dinis el máximo representante de una etapa o estilo denominado gallego, opuesto al estilo provenzal, más artificial, aristocrático y mimético respecto a la influencia occitana, permite la asimilación por parte portuguesa del espíritu de pueblo que se cree presente

\footnotetext{
${ }^{62}$ Sobre la reivindicación de las Cantigas de Santa María en la época del Rexurdimento, vid. LóPEz, De lírica art. cit."," p. 283; Idem, Andrés Martínez Salazar art. cit., pp. 236-237). 'A las dificultades de apropiación' del cancionero mariano alfonsí por parte de la literatura gallega ya nos hemos referido en el trabajo mencionado GUTIÉRREZ GARCÍA, Consideracións art. cit." pp. 2947. La suerte de las Cantigas de Santa María dentro del discurso crítico gallego, por lo tanto, puede ponerse en relación, con la de la llamada escuela gallegocastellana o escuela de decadencia.

${ }^{63}$ Francisco RODRÍGUEZ SÁNCHEZ, Definición, características e periodización da literatura galega, en A. Asende Estraviz y C. Sảnchez Iglesias (coords.), Historia da literatura galega, I,
A Idade Media, Vigo, 1996, pp. 12-13.

${ }^{64}$ VILLARES, Breve historia op. cit., p. 96.

${ }^{65} \mathrm{El}$ cancionero individual de $\mathrm{D}$. Dinis lo componen ciento treinta y siete cantigas, que formaron un corpus textual independiente antes de incorporarse, en el primer cuarto del siglo XIV, a las compilaciones poéticas generales (António RESENDE DE OLIVEIRA, Depois do espectáculo trovadoresco. A estrutura dos cancioneiros peninsulares e as recolhas dos séculos XIII e XIV Lisboa, $1994 . \mathrm{pp}$. 193-194; Idem, O trovador galego-português e o seu mundo, Lisboa, 2001, pp. 269-273 y 327-328).

${ }^{66}$ Caetano LOPES DE MOURA, Cancioneiro d'El-Rei D. Diniz, pela primeira vez impresso sobre o Manuscripto da Vaticana, Paris, 1847-1848. Vid., igualmente, la edición de Henry R. LANG, Cancioneiro d'El-Rei Dom Denis zum ersten Mal vollständig herausgegeben, Halle, 1892.
} 
en las cantigas de amigo. De este modo se salva la contradicción, observada por Lapa ${ }^{67}$, que suponía minimizar el aporte galaico en la conformación de la escuela lírica y al mismo tiempo constatar que la literatura gallega permanece más cercana al Volkgeist a través del folclore.

Al margen de los mecanismos de apropiación mencionados hasta el momento, la literatura portuguesa dispone de un nuevo ámbito de actuación, del que también carece la gallega, en la legitimación a través de los artefactos, es decir de los cancioneros. En este sentido, al norte del Miño se muestra una penuria absoluta, puesto que tanto los códices que contienen la producción de la lírica profana como los de la mariana no reflejan vinculación directa con los medios de producción literaria de la Galicia medieval. Además de las Cantigas de Santa María, a las que ya nos hemos referido más arriba, los apógrafos italianos, compuestos y descubiertos en Italia, supuestamente remontan al Livro das cantigas, recopilado por el conde D. Pedro de Barcelos, y uno de éstos, junto al Cancioneiro da Ajuda, antiguo Cancioneiro do Colégio de Nobres, se encuentra depositado en Portugal. Por último, las dos hojas de pergamino con cantigas de Martin Codax y de D. Dinis, conocidas como Pergamino Vindel y Pergamino Sharrer, o bien tampoco se relacionan con el ambiente cultural gallego o bien se encuentran depositadas fuera de Galicia ${ }^{68}$.

La importancia a este respecto de los artefactos se observa desde el lado contrario, ya que buena parte del refrendo que en este aspecto le concedían los críticos foráneos a la literatura portuguesa, ya en el siglo XIX, procedía de la identificación como lusitanos de los cancioneros. El soporte material que proporcionan las compilaciones medievales sirve, por otro lado, como manifestación de una institución capaz de legitimarse trasladando al plano de lo inmediato la atribución simbólica de la propia lírica, gracias a la concepción monumentalista del pasado que se consigue con la posesión de este tipo de reliquias ${ }^{69}$. En este sentido, debe reconocerse la legitimidad que el sistema portugués obtiene de la filiación cultural de los cancioneros $A, B$ y $V$, que se manifiesta en afirmaciones como la de J. da Cunha Neves Carvalho ${ }^{70}$, quien, compartiendo la idea de atraso cultural que asimismo expresaba Braga, consideraba, a mediados del siglo XIX, que el descubrimiento del Cancioneiro da Ajuda había permitido que los conocimientos lingüísticos y filológicos portugueses se pusiesen al nivel de los de las otras naciones. No obstante, más significativa resulta la compra por parte del gobierno portugués del cancionero $B$, antes conocido por el nombre de Colocci-Brancuti, y que, como observa

\footnotetext{
${ }^{67}$ LAPA, Lições op. cit., p. 97.

${ }^{68} \mathrm{El}$ Pergamino Vindel $(N)$, con cantigas de Martin Codax, fue dado a conocer en Madrid por el librero $\mathrm{P}$. Vindel, mientras que el Pergamino Sharrer $(D)$, identificado por el estudioso americano H. Sharrer contiene cantigas de D. Dinis y pertenece a los fondos de la Torre do Tombo de Lisboa. Vid. Sobre los testimonios textuales gallegoportugueses TAVANI, A poesía op. cit., pp. 51 y ss.; Manuel Pedro FERREIRA, Pergaminho Vindel, en Lanciani y Tavani, Dicio
op. cit., p. 536; Harvey L. SHARRER, Pergaminho Sharrer, en Idem, Ibid., pp. 534-536.

${ }^{69}$ Vid. sobre este concepto Xoán GonZÁlEZ-MiLlán, A constitución monumentalista do pasado, "A Trabe de Ouro", LIV (2003), pp. 157-168.

${ }^{70}$ CARVAlHO, Noticia art. cit., p. 325.
} 
J.-M. d'Heur ${ }^{71}$, le fue vendido por los antiguos propietarios, los herederos de E. Monaci, a precio de oro. La llegada del manuscrito a Portugal dio ocasión a un acto oficial de recibimiento, con una alocución de J. Leite de Vasconcelos en la que destacó «o prazer... de lhe chamarmos nosso [al códice]» y propuso el cambio de nombre como culminación del proceso de apropiación: «daqui em adiante poderá chamar-se da Biblioteca Nacional de Lisboa» ${ }^{72}$, designación esta por la que se le conoce desde entonces.

Finalmente, los mecanismos de hegemonización pueden condicionar incluso la labor filológica, determinando los criterios lingüísticos utilizados a la hora de editar los textos trovadorescos. Así, el hecho de que los testimonios textuales más completos - los cancioneros ya citados ${ }^{73}$ - procedan de la zona portuguesa determina unos usos gráficos y lingüísticos que luego recogerán los editores a la hora de establecer los textos críticos ${ }^{74}$. Ahora bien, desde el lado gallego, y cuando se editan autores nacidos en Galicia, a veces puede buscarse lo que $\mathrm{H}$. Monteagudo ${ }^{75}$ describe como «tentativa de adaptación e uniformización da grafía dos cancioneiros segundo criterios galegos», obviando la supuesta unidad cultural gallegoportuguesa, ante lo que se considera una excesiva presencia de los elementos portugueses ${ }^{76}$. Tales son los argumentos, por ejemplo, que aduce en su edición de las cantigas de Pai Gomez Charinho A. Cotarelo Valledor. Este parte de la diferencia que existía en el siglo XIII entre las dos lenguas, así como de las grafías no portuguesas que presentan otros testimonios ajenos a los apógrafos italianos, como el Pergamino Vindel $(N)$ y las Cantigas de Santa María, o incluso la prosa medieval gallega. Por tal razón, opta por «restablecer la ortografía trecentista gallega, no portuguesa, apartándonos de la versión vaticana en cuanto no afecte al sonido» ${ }^{77}$.

\footnotetext{
${ }^{71}$ D'Heur, Troubadours d'oc, op. cit., p. 39, nota 36. 252.

${ }^{72}$ José LeITE de VASCONCElos, Cancioneiro de Colocci-Brancuti, “Lusitania”, 1 (1924), p.

${ }^{73}$ Como apuntamos más arriba, estos dos cancioneros, también conocidos como apógrafos italianos, acaso desciendan de una compilación realizada en Portugal a comienzos del siglo XIV Nacional .(Colocci-Brancuti), Lanciani y Tavani, Dicionário op. cit., pp. 119-123; Idem, Cancioneiro da Biblioteca Vaticana, en Idem, Ibidem, pp. 123-126.

${ }^{74} \mathrm{Las}$ ediciones críticas suelen preferir las lecturas que ofrecen $A$ y $B$, pero, vid. infra, nota 79 para la lusificación de las grafías del Cancioneiro dá Ajuda que llevó a cabo Michaëlis.

${ }^{75}$ Monteagudo, Prólogo art. cit., p. xii.

${ }^{76}$ Vid., por ejemplo, la siguiente declaración de Ramón LORENZO, Normas para a edición de textos medievals galegos, en Kremer (ed.), "Actes du XVIII" Congrès International de Linguistique et de Philologie Romanes op. cit.", IV, pp. 77: «Deixando fóra as edicións dos poetas trovadorescos, feitas case sempre con criterio portugués...».

${ }^{77}$ Cotarelo VAlledor, Cancioneiro op. cit., p. 143. Relacionada con esta línea de actuación estaría la adaptación de los textos de las cantigas a gallego moderno, como la que, con propósitos divulgativos, llevó a cabo A. de las Casas en su antología de poesía gallega (Álvaro DE LAS CASAS, Antología de poetas. El ciclo trovadoresco. La decadencia. Los precursores. El Renacimiento. La poesia nueva, Buenos Aires, 1939) o, hace pocos años, B. Graña en otra antología de Cantigas de Santa María (Bernardino GRAÑA, Cantigas de Santa María de Alfonso antología de Cantigas de Santa Maria (Bernardino GRANA, Cantigas de Santa Maria de Alfonso segundo de estos autores al «complexo de autodesprezo» que lleva a los gallegos al olvido de sus lengua y tradición cultural. Este género de afirmaciones, por lo demás, y como veremos más adelante, son comunes a otro tipo de actuaciones, tal que las ediciones de trovadores, sentidas como mecanismo de recuperación.
} 
Algunas de las ideas expuestas hasta ahora pueden ponerse en relación con las decisiones lingüísticas adoptadas por la crítica en la edición de las cantigas de Martin Codax, en lo que respecta a la reproducción gráfica de los fonemas nasal palatal y lateral palatal. La relevancia de este autor radica en dos aspectos: su condición de juglar asimilado por el canon gallego a través de las alusiones a Vigo que contienen sus cantigas de amigo y la transmisión de sus piezas a través de un testimonio textual -el Pergamino Vindel-ajeno a la tradición de los apógrafos $B$ y $V$. De manera sintomática, el brasileño $C$. Cunha $^{78}$ prefería en su edición las grafías $n h$ y $l h$, usadas en los apógrafos italianos, sobre $n n$ y $l l$, que aparecen en $N$, pues consideraba que estas últimas podían ser «causadoras de ambiguidades» ${ }^{7}$. Por contra, en sendas ediciones realizadas en Galicia ${ }^{80}$ se priman los dígrafos de $N$ por encima de los de $B$ y $V$. Cierto es que ante opciones ecdóticas de este género, la explicación se atiene a criterios puramente filológicos, pero tampoco podemos obviar la dimensión ideológica de la propia Filología. En este respecto, resulta reveladora la observación de Méndez Ferrín, quien, desde la postura integradora gallegoportuguesa, defendía en estos términos las formas $\mathrm{nh} / \mathrm{lh}$ en la edición del juglar Pero Meogo:

Escribimos $n h$ e $l h$ pra representar a palatal nasal sonora e a fricativa lateral
sonora, isto é, o mesmo que en $C V$ e $C B$. Non consideramos oportuno
utilizar as grafías hespañolas $\tilde{n}, l l$ por consideralas alleas non tanto á
tradición textual galega, como á tradición conxunta galega e portuguesa. Na
nosa opinión os textos poéticos medievás deberan sempre ser editados con
istes siños provenzalizantes, por ser iste o procedemento empregado nos
dous grandes apógrafos ${ }^{81}$.

La concesión, por parte de un estudioso gallego como Ferrín, de la importancia que asume el sistema gráfico de los apógrafos italianos a la hora de fijar los criterios de edición de la lírica medieval, no deja de ser un triunfo implícito de los planteamientos de la crítica portuguesa, ya que ésta emplea los dígrafos $l h$ y $n h-a l$ margen de otras soluciones gráficas sobre las que no nos detendremos- como medio de acercar la lengua trovadoresca a la norma del portugués actual. Así se explica que los filólogos de ese país acepten los usos escriturarios de $B$ y $V$ y obvien los del Cancioneiro da Ajuda, el único de los testimonios textuales conservados que sería contemporáneo al florecimiento

${ }^{78}$ Celso CunHa, Cancioneiro de Martin Codax, en E. Gonçalves (ed.), Cancioneiros dos trovadores do mar, Lisboa, 1999.

${ }^{79}$ Este criterio de la claridad como explicación para sustituir los dígrafos $l l / n n$ por $n h / l h$ remonta a la edición dẹl Cancioneiro da Ajuda de Michaëlis, quien, por cierto, incluía un no velado propósito de nacionalización de la lengua trovadoresca: Bani os símbolos $n n$, $l l$ por serem estranjeirismos anti-etimolójicos, não sòmente inúteis, mas enganadores. Escolhi $n h$, $l h$ porque

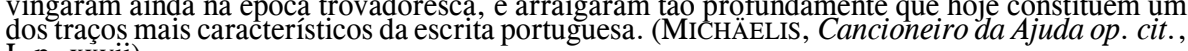
dos traços m. Xxvii).
I,

${ }^{80}$ Mercedes BREA (coord.), Cantigas do Mar de Vigo. Edición crítica das cantigas de Meendinho, Johan de Cangas e Martin Codax, Santiago de Compostela, 1998; Xose Ramón

${ }^{81}$ Xosé Luís Méndez Ferrín, O cancioneiro de Pero Meogo, Vigo, 1966, pp. 129-130 
poético gallegoportugués. El problema reside en que, a pesar de que, como acabamos de ver $A$ pertenece simbólicamente al acervo cultural portugués, no sólo se duda de su lugar de composición, sino que emplea grafías como la $l l$ y $n n$, anteriores a la reforma impulsada por Alfonso III, la cual fijó la norma del portugués actual, para lo que afecta al sistema de reproducción gráfica de los fonemas que nos ocupan.

Frente a lo anterior, la potenciación del papel de Santiago de Compostela en la eclosión y el desarrollode la lírica trovadoresca se configura como un mecanismo más efectivo, desde el punto de vista gallego, en lo que respecta a su enfrentamiento con la literatura portuguesa, ya que esta no dispone en tal aspecto de capacidad de réplica. La importancia de esta ciudad como foco cultural llevó a numerosos estudiosos a identificarla como uno de los centros aglutinadores de la escuela poética gallegoportuguesa, a pesar de que no faltan voces que matizan su papel con el argumento de que se trata de un foco cultural vinculado al ámbito eclesiástico y no a los centros nobiliarios, que serían, según este punto de vista, los que favorecieron con su mecenazgo a los primeros trovadores ${ }^{82}$. Por tal motivo, se ha buscado la relación de la ciudad con algún linaje nobiliario gallego, como el de los Traba, que desempeñó un papel destacado en la política castellanoleonesa, así como en la promoción de la lírica a comienzos del siglo XIII ${ }^{83}$ y del que se sabe que tenía posesiones en dicha urbe. No obstante, las propiedades compostelanas de los Traba no aseguran directamente el papel que se le atribuye a Santiago en la eclosión del fenómeno trovadoresco. De hecho, también existen objeciones que parten de la escasa documentación existente que demuestre la presencia trovadoresca en la ciudad del Apóstol ${ }^{84}$.

Lapa $^{85}$, a pesar de que en otros aspectos no dudaba en reconocer el aporte gallego en el surgimiento de la lírica, consideraba que la exaltación del papel de Compostela se debía a la labor de cinco críticos - Lang, Michaëlis, Menéndez Pelayo, López Ferreiro y Oviedo y Arce-, de los que dos eran gallegos y un tercero, Menéndez Pelayo, actuaba desde el sistema castellano. La fortuna del argumento, basado en el impulso de las peregrinaciones y en la supuesta concurrencia de juglares transpirenaicos a Galicia, fue recogida por

\footnotetext{
${ }^{82}$ Vid. el estudio de las casas nobiliarias y su papel en el desarrollo de las etapas iniciales de la lírica gallegoportuguesa en DE OLIVEIRA, O trovador op. cit., passim y José Carlos RIBEIRO MIRANDA, Aurs mesclatz ab argen. Sobre a primeira geraça a de trovadores galego-portugueses, MIRANDA, Aurs mesclatz ab argen. Sobre a primeira geraçáa de trovadores galego-portugueses, juglaresca, tal y como hace Lapa, Liçóes op. cit., pp. 74-75, quien concede más importancia a juglaresca, tal y como hace Lapa, Liçóes op. cit.,pp. 74-75, quien concede más importa
otros centros, como los portugueses de Nossa Senhora da Oliveira o de São Torcato.

${ }^{83}$ Yara FRATESCHI VIEIRA, En cas dona Maior: os trovadores e a corte senhorial galega no século XIII, Santiago de Compostela, 1999.

${ }^{84}$ Manuel VÁZQUEZ DE PARGA, Peregrinaciones a Santiago de Compostela, Pamplona, 1993 ( $1^{\text {a }}$ ed. 1948), I, pp. 516-517; Jean-Marie D'HEUR, Saint-Jacques-de-Compostelle et Saint Jacques le Majeur dans la littérature occitane, "Annales du Midi", LXXIX (1967), pp. 255-268. Aunque el primero de estos autores, incluso reconociendo la «falta absoluta de datos concretos sobre una primitiva lírica vulgar compostelana» (VÁZZUUE DE PARGA, Peregrinaciones op. cit. $\mathrm{I}, \mathrm{p}$. 516), acepta la importancia del culto jacobeo, junto a la vinculación de los reyes leoneses con Galicia, en la génesis de la lírica vulgar.

${ }^{85}$ LAPA, Lições op. cit., p. 79.
} 
Nunes $^{86}$ y ha llegado hasta nuestros días ${ }^{87}$. Mas, al margen de la capacidad probatoria de los argumentos a favor o en contra, el mecanismo que subyace muestra sus coincidencias con la estrategia de Braga de postular como centros culturales las cortes de los sucesivos monarcas lusitanos en Guimarães y Lisboa, con el propósito implícito de contrarrestar el olvido, por parte del aludido erudito portugués, del papel que habrían desempeñado las tierras al norte del Miño en el surgimiento de la escuela trovadoresca. Por lo que respecta a Galicia, la ausencia de una continuidad dinástica y las carencias en lo que se refiere a instituciones políticas propias condujeron a la potenciación de la capitalidad religiosa o, en su defecto, del protagonismo compostelano en las revueltas que tuvieron lugar durante la minoridad de Alfonso Raimúndez. La funcionalidad de Compostela en la reivindicación gallega de la lírica medieval va, por lo tanto, unida a la capacidad de representar el papel de la institución, a través del estatuto de capitalidad simbólica, en un proceso nacionalitario interrumpido.

\section{CONCLUSIONES}

Las relaciones entre los sistemas gallego y portugués se definen, como apuntamos páginas más arriba, por la situación de descompensación enunciativa que determina la minorización de la literatura gallega. Entre los mecanismos de reafirmación de que esta dispone, desde su condición vicaria, surge el referente de integración que proporciona la literatura portuguesa, lo que le permite distanciarse del sistema castellano, pero no evita que se mantengan las relaciones desiguales con el nuevo referente. Así lo demuestra la asimetría sobre la que se construye la interrelación entre el norte y el sur del Miño, centradas, en general, en la admiración y emulación, a menudo no correspondidas, por parte de los agentes culturales gallegos hacia la cultura portugue$\mathrm{sa}^{88}$.

'José Joaquim NUNES, Trovadores e jograis galego-portugueses, “Biblos”, I (1925), pp.

${ }^{87}$ Vid., por ejemplo, TAVANI, A poesía op. cit , pp. 27-32 y Teresa GARCÍA-SABELL, Compostela y los trovadores, en X. L. Couceiro et alii (eds.), "Homenaxe ó Profesor Camilo Flores", Santiago de Compostela, 1999, pp. 364-378 0, desde la tradición de estudios documentales gallegos, José Antonio SouTo CABO, Airas Fernandes Carpancho e Nuno Eanes de Cêrcio en "O Cancioneiro da Ajuda cen anos despois. Actas do Congreso realizado pola Dirección Xeral de Promoción Cultural en Santiago de Compostela e na Illa de San Simón os días 25-28 de maio de 2004", Santiago de Compostela, 2004, pp. 473-83 y José Antonio SOUTO CABO y Yara FRATESCHI VIEIRA, Para um novo enquadramento histórico-literario de Airas Fernandes, dito "Carpancho", "Revista de Literatura Medieval", XVI / 1 (2004), pp. 221-277.

${ }^{88}$ Vid. VÁZQUEZ CUESTA, Portugal art. cit., pp. 41-53; Idem, Relacións entre as literaturas galega e portuguesa, en "Actas do I Congreso Internacional da Cultura Galega", Santiago de asimetrico, "Coló, puio p. Letras", CXXXVIII-CXXXVIII (1995), pp. 6-21. Lo que no impide cierta valoración de Galicia en la etapa fundacional de la cultura portuguesa. Vid., por ejemplo, la dedicatoria de Lapa en su edición de las cantigas de escarnio y maldecir, en la que denomina a Galicia «raíz anterga da nosa cultura» (Manuel RODRIGUES LAPA, Cantigas d'escarnho e de mal dizer dos cancioneiros medievais galego-portugueses, Vigo, 1965, p. v). Sin embargo, este tipo de reconocemiento no deja de ser minoritario. 
Esta situación, sin embargo, no impide alguna situación discursiva particular en la que esa misma emulación deja paso a una competencia que forma parte de los propios mecanismos de autoafirmación y construcción canónica. Tal acontece, por ejemplo, cuando afloran las ambigüedades enunciativas de dos sistemas que pugnan por la apropiación de la lírica trovadoresca. Esta permite la constitución, por un lado, de una comunidad cultural intersistémica, pero por otro no prescinde de los intentos de delimitación canónica que eviten que la integración se convierta en desposesión. En este punto surge, una vez más, la posición subalterna de la literatura gallega, que acentúa el propósito reivindicativo de sus enunciados, partiendo de la base de que los discursos nunca son neutros y de que el simple estudio de un objeto artístico forma parte de una estrategia de apropiación ${ }^{89}$.

Esta voluntad performativa se percibe desde los primeros trabajos que redescubren la poesía lírica medieval, tanto por parte portuguesa como gallega, ya que forma parte del proceso de construcción de las literaturas nacionales del siglo XIX y buena parte del XX. Ahora bien, el dispar grado de desarrollo institucional, que finalmente se mantiene a lo largo de este último siglo favorece asimismo las estrategias de reclamación que aún hoy en día se pueden observar en ciertos trabajos sobre lírica gallegoportuguesa publicados en Galicia. Así sucede, por ejemplo, con declaraciones como las de M. Ferreiro, con motivo de la edición de Rodrigu'Eanes de Vasconcelos, quien, todavía a finales del siglo XX, manifestaba su voluntad de dar a conocer el pasado literario y cultural gallego como parte de una reivindicación de tipo nacionalitario ${ }^{90}$. Una declaración de este género no puede por menos que ponerse en relación con la que, en 1841 publicó en El idólatra de Galicia Neira de Mosquera (en "Apuntes para la historia de la literatura gallega"), en la que denunciaba el olvido en el que se encontraban muchos trovadores; también, con la dedicatoria que T. Vesteiro Torres incluyó en el ejemplar de la edición del Cancioneiro da Vaticana realizada por Monaci, que él mismo donó en junio de 1876 a la Universidad de Santiago de Compostela, en la que expresaba su propósito de ayudar al Rexurdimento literario gallego, dando a conocer la obra ignorada de los trovadores ${ }^{91}$.

Sin embargo, el literario no es ni el único campo ni el más complejo en el que se desarrollan las relaciones entre Galicia y Portugal. Basta con

\footnotetext{
${ }^{89}$ Pierre Bourdieu, Ce que veut parler, Paris, 1982, p. 144. Vid. también, FiguEROA, Literatura, nación op. cit., p. 71.

${ }^{90}$ Manuel FERREIRO, As cantigas de Rodrigu'Eanes de Vasconcelos. Edición con introdución, notas e glosário, Santiago de Compostela, 1992, p. 23 . En términos parecidos se expresa F. Pillado Mayor, en el prólogo a la edición de Ferreiro, ya que habla de la lírica trovadoresca como parte de una tradición, cuyos destinatarios serían «entre outros, todos os galegos», destaca el acto de recuperación de la memoria compartida de los gallegos que supone un trabajo de este género

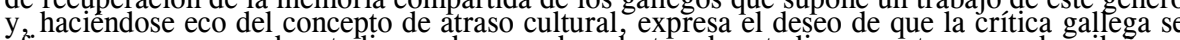
afiance en un campo de estudio en el que ya han destacado estudiosos portugueses, brasilenos e italianos (Ibid., pp. 7-8). Por lo demas, en esta edición, la elección de un trovador de origen portugués indica que el autor niega las contradicciones entre los discursos de hegemonización gallego y portugues y opta por este segundo como referente de integración.

${ }^{91}$ LÓPEZ, De lírica art. cit., pp. 284-85.
} 
considerar el aspecto lingüístico ${ }^{92}$ para corroborar que las consideraciones anteriores se inscriben en un discurso cultural más amplio, definido a partir de la dualidad autoafirmación-(re)integración.

De todas formas, justo es reconocer que esta actitud de distanciamiento por parte gallega que se acaba de describir en estas páginas no impide la expresión mayoritaria del recurso a la integración, de tal manera que la citada dualidad non debe verse como una pareja de estrategias antitéticas, sino como aspectos complementarios de un mismo procedimiento de construcción discursiva sujeto a muy diferentes interpretaciones. Así, y sirva este último ejemplo para cerrar las presentes reflexiones, recuérdese la propuesta del portugués A. Sardinha ${ }^{93}$, quien, desde su ideología integralista e iberista veía la lírica gallegoportuguesa como exponente histórico de la colaboración entre los diversos pueblos peninsulares, al tiempo que invitaba al nacionalismo gallego a servir de puente entre España y Portugal y a encabezar el proyecto de unión ibérica ${ }^{94}$. Y no debe olvidarse, al respecto, que una propuesta semejante, que asumía las esencias de la doctrina iberista, ha sido formulada con una cierta continuidad también desde el ámbito del galleguismo ${ }^{95}$.

Fecha de recepción del artículo: abril 2006.

Fecha de aceptación y versión final: marzo 2007.

${ }^{92}$ Vid., por ejemplo, Elías J. TORRES FEIJÓ, Norma lingüística e (inter-)sistema cultural. O caso galego, en J. M. Carrasco González et alii (eds.), "Actas del Congreso Internacional de Historia y Cultura en la Frontera. $1^{\circ}$ Encuentro de Lusitanistas Españoles", Cáceres, 2000, II, pp. 967-996.

${ }_{93}^{93}$ António SARDINHA, Nacionalismo Galego e Lirismo Português, "Nação Portuguesa. Revista de Cultura Nacionalista", III (1925), pp. 130-36.

${ }^{94}$ Ibid., p. 135.

${ }^{95}$ VÁZQuez Cuesta, Portugal art. cit., pp. 198 y ss. 